\title{
SALINE LAKE LIMNOLOGY - SASKATCHEWAN STYLE
}

\section{U. THEODORE HAMMER, Professor Emeritus, Biology Department, University of Saskatchewan, Saskatoon, SK. S7N OWO}

Saline lakes are found on every continent. They make up almost $50 \%$ of all world lakes in both surface area and volume. ${ }^{20}$ In Saskatchewan they are found in the southern part of the province within the grassland and parkland vegetation zones (Fig. 1). These saline lakes (about 535) make up only about $0.7 \%$ of the Saskatchewan lake total, ${ }^{6}$ in contrast to many parts of the world (Australia, the Asian portion of the old USSR, Iran, southwestern United States,
Kenya-Tanzania) where saline lakes predominate. $^{4}$

Salinity, Climate and Geology Lakes are defined as saline if they contain 3 grams per litre or more of dissolved salts. ${ }^{21}$ This may be compared to $0.5 \mathrm{~g} / \mathrm{L}$ or less salt in potable drinking water (fresh water) and an average of $35 \mathrm{~g} / \mathrm{L}$ salt in sea water. The single most important determining factor is climate as saline lakes are usually found where

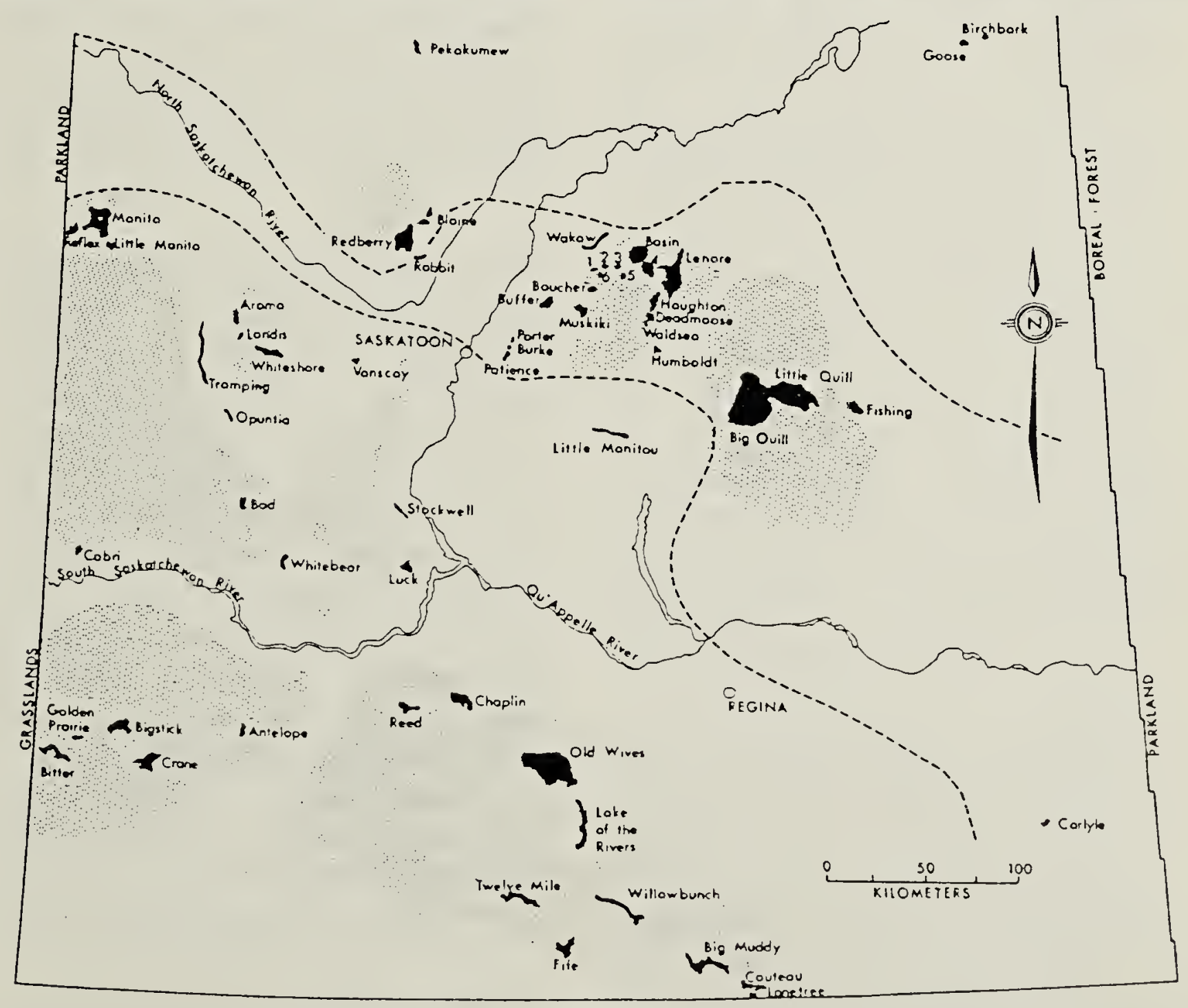

1 Olivier 2 Arthur 3 Soyer 4. Middle 5. Lovis 6 Motie

Figure 1. Southern Saskatchewan showing the location of saline lakes (black), vegetation zones, and endorheic drainage basins (stippled). ${ }^{12}$ 
evaporation exceeds precipitation. In Saskatchewan suitable climates are semiarid in the southwest (grasslands) and subhumid (aspen parkland) further north and east. Average annual precipitation in southern Saskatchewan varies from 30 to 40 $\mathrm{cm}$ while evaporation may range from about $100 \mathrm{~cm}$ annually in the Lake Chaplin area to lesser amounts to the north and east. The major source of water for lakes in southern Saskatchewan is from snowmelt runoff. Although lake depths and volumes increase directly through rainfall, significant influent runoff from a drainage basin surrounding a lake does not occur unless there is heavy or prolonged rainfall. About 60 lakes with areas greater than one square kilometre have been described ${ }^{9}$ as to location and structure. The largest in area is Big Quill Lake $\left(307 \mathrm{~km}^{2}\right)$ while the deepest is Deadmoose Lake (48 metres). However, saline lake mean depths do not exceed 10 metres and many are very shallow.

The lakes are located on glacial till that have fine clay sediments in lake bottoms permitting water retention. Saline lakes are located within endorheic (internal) drainage basins and do not flow out into larger rivers and then into the sea as do northern Saskatchewan river systems. This allows the salts derived from soils rich in minerals to be dissolved in runoff waters and retained in lakes where they are concentrated when

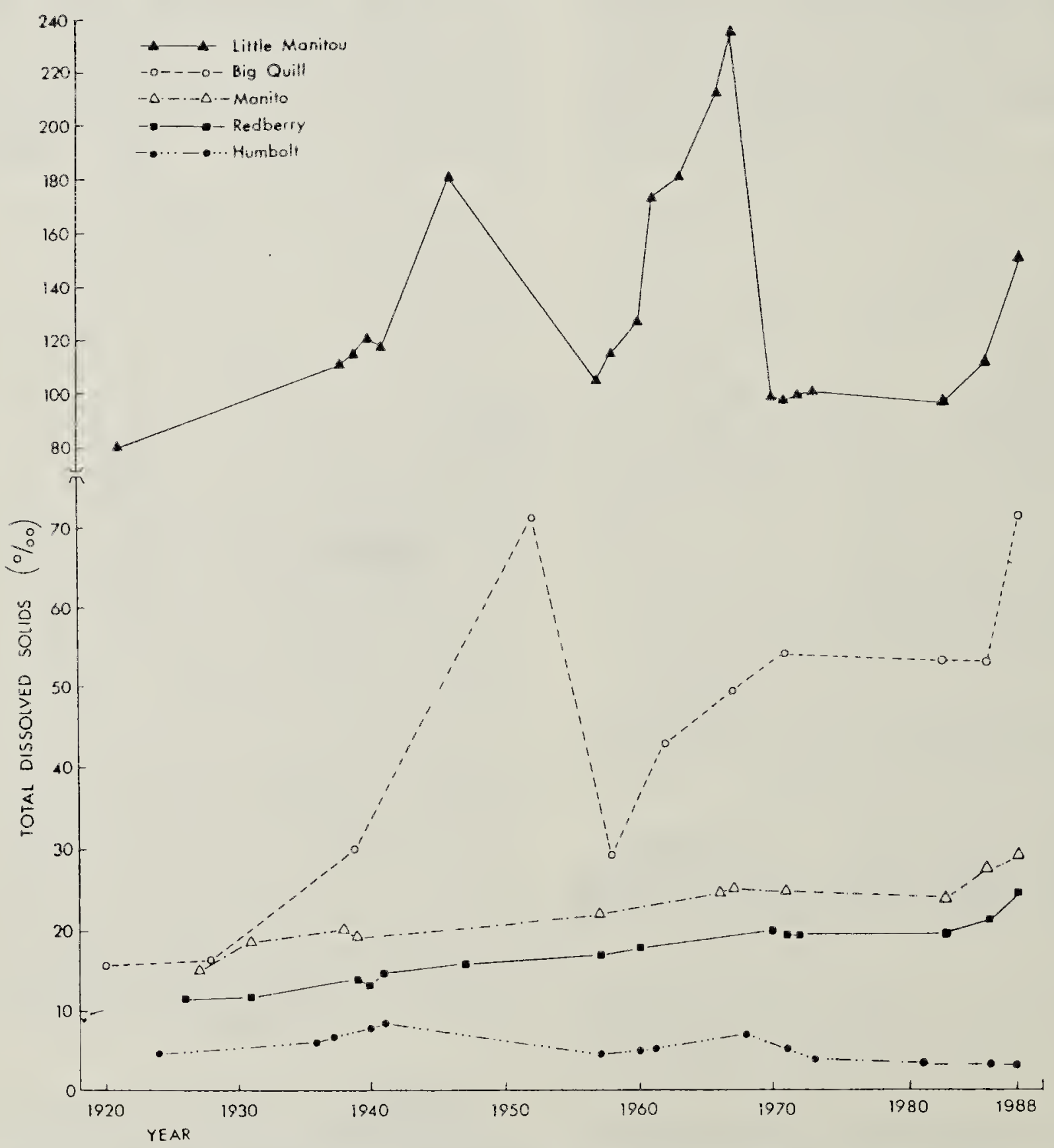

Figure 2. Long term changes in total dissolved solids (=salinity) in five Saskatchewan lakes, 1920-1988. 
evaporation occurs, that is, the waters become saline. Thus fluctuation in precipitation, water inflows and evaporation all contribute to changes in lake water salinity (Fig. 2). The droughts of the 1930s, 1960s and 1980s resulted in increasing lake salinities, while high precipitation particularly in winter snowpacks during the 1950s and 1970s decreased lake salinities. The greater the salinity, the greater the long-term fluctuations, e.g. Little Manitou Lake. Shallower lakes such as Big Quill Lake also fluctuate more than deeper lakes such as Manito and Redberry lakes. Low salinity lakes like Humboldt and Wakaw fluctuate relatively little in salinity. Seasonal changes in salinity also occur as salinity increases from spring to fall. More saline and shallow saline lakes tend to increase more in salinity seasonally, while lakes such as Humboldt show little change. Salinities range from slightly saline Humboldt and Wakaw lakes to highly saline Big Quill, Little Manitou and Patience lakes. Patience Lake has had more than 10 times sea water salinity.

Water Chemistry The chemical constituents of Saskatchewan saline lakes are dominated by the cations sodium and magnesium, with calcium and potassium at much lower levels. ${ }^{3}$ Sodium tends to be dominant in most of the world's saline lakes. (Potassium is second to sodium in $\mathrm{Pa}$ tience Lake which derives much of its salts from potash mine wastes on its shores.) The anion which dominates is sulphate, with chloride or carbonate/bicarboriates secondary. Chloride from potash mine wastes is the dominant anion in Patience Lake. Saskatchewan fresh waters are primarily sodium bicarbonate-carbonate.

The important nutrients phosphorus and ammonia are usually abun- dant in saline lakes. These lakes are also alkaline in Saskatchewan with the $\mathrm{pH}$ range from 7.5 to 10.00 .

Physical Factors Light penetrates deeply into clear lakes like Redberry but is absorbed very quickly in turbid lakes such as nearby Rabbit Lake. ${ }^{9}$ Turbidity is caused by inorganic and organic matter stirred up from shallow lake bottoms or by the growth of algae and bacteria in the waters and by pigments leached out of plant materials.

Deeper lakes stratify thermally so that the bottom waters remain cold all year round, e.g. Redberry, Manito, Deadmoose. Shallow lakes are mixed by the wind and warm up throughout with increasing light and air temperature.

Water temperature varies from $0^{\circ} \mathrm{C}$ under the ice up to $30^{\circ} \mathrm{C}$ in shallow surface waters in summer. In southern Saskatchewan the winter ice cover usually reaches about one metre thick whether the lakes are fresh or saline. As the temperature drops to just above freezing, salt precipitates out as sodium sulphate so that saline lake water is then much fresher and can freeze. This principle is used to harvest sodium sulphate, e.g. at Chaplin. An exception occurs in Patience Lake. ${ }^{11}$ Chloride salts in this lake are highly soluble so that the freezing point is depressed and the lake does not freeze until its water reaches about $-25^{\circ} \mathrm{C}$ !

Five Saskatchewan saline lakes in the Humboldt region (Deadmoose, Waldsea, Sayer, Marie, Arthur) are or have been meromictic ${ }^{8}$ (lower water in a lake is heavier than water nearer the surface). This happens when fresh water flows in over the top of more saline waters, as when snowmelt waters flow in during spring 
runoff. If enough fresh water enters, the lighter surface waters cannot be mixed by the wind with the heavier lower waters. There is a marked transition, chemically, between the two zones (chemocline) and the lake is said to be meromictic. No oxygen is present in the lower denser waters so life there is limited to large populations of anaerobic bacteria.

Lake Biology The flora and fauna present in saline lakes are determined by the broad range of salini- ties. The greatest number of species in any group of organisms occurs in lower salinities. Of particular interest is the fact that the most species occur in the transition zone, around 3 g/L.

Algae Algal populations are the basis of the food chain in lakes. Algae from 41 Saskatchewan saline lakes have been identified and discussed. ${ }^{12}$ Two hundred and twelve species and varieties in 7 phyla, 8 classes, 42 families and 91 genera

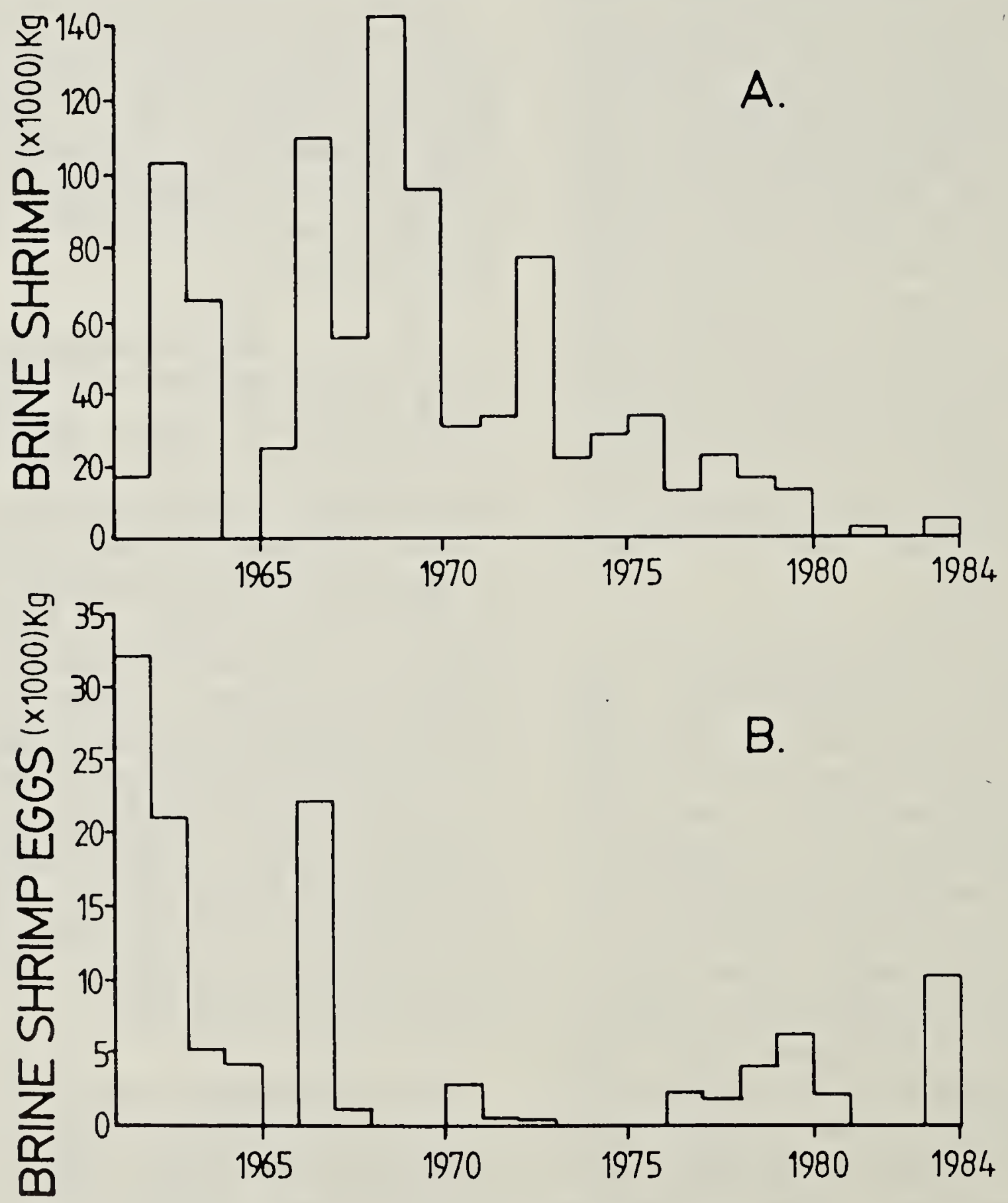

Figure 3. Typical algal species: green algae A. Cladophora crispata (Big Quill L.), E. Pediastrum Boryanum (Humboldt L.); diatoms B. Stephanodiscus niagarae (Manito L.), F. Navicula cincta (Little Manitou L.); C. the flagellate Ceratium hirundinella (Wakaw L.); D. blue-green algal bloom in Humboldt L.(Anabaena flos-aquae, Lyngbya Birgei, Microcystis aeruginosa). 
were identified. Fourteen species were restricted to hypersaline $(50 \mathrm{~g} / \mathrm{L}$ or more) waters and 11 of these were diatoms. Twenty-five species were abundant in low salinity waters (3-5 g/L) - 9 diatoms, 6 greens, 8 blue-greens and 2 dinoflagellates. Blue-green algae such as Aphanizomenon flos-aquae, Microcystis aeruginosa and Anabaena flos-aquae are common sources of water blooms (so dense they colour the water) and are also abundant in fresher waters such as in lakes of the Qu'Appelle River Valley.

Highly saline lakes (Muskiki, Chaplin, Little Manitou, Deadmoose, Waldsea) were dominated by populations of diatoms and green algae. In less saline lakes ( $<10 \mathrm{~g} / \mathrm{L}$ ), such as Humboldt, Lenore and Wakaw, diatoms dominated in the spring and fall and blue-greens in the late spring through fall.

The rate of primary productivity decreased with increasing salinity. ${ }^{14}$ The highest rates were associated with algal blooms: Aphanizomenon flos-aquae, Microcystis aeruginosa, Stephanodiscus niagarae in Humboldt Lake; Nodularia spumigena in Manito Lake. Mixed populations rather than specific algal blooms occurred in other lakes (Fig. 3). The productivity in Humboldt Lake is one of the highest ever measured anywhere. High concentrations of nutrients, including phosphorus and nitrates from sewage effluent and farmland and feedlot runoff, are the basis for the high production. The $613 \mathrm{~g} \mathrm{C} / \mathrm{m}^{2} / \mathrm{yr}$ is roughly equivalent to a wheat crop of 100 bushels of wheat per acre.

Bacteria Photosynthetic sulphur bacteria have only been examined in the meromictic lakes, particularly Waldsea and Deadmoose lakes. ${ }^{15,16}$ These bacteria were most abundant in a layer referred to as the bacterial plate present in the chemocline. This is a zone of low light, no oxygen and cold water. In the process of photosynthesis, hydrogen sulphide is converted to sulphate as carbon is assimilated. No oxygen is produced as in algae and higher plants. Chlorobium sp., a green sulphur bacterium, was dominant in Waldsea Lake. The water of the plate was coloured pinkish brown. The bacteria actively photosynthesize the whole year even under the ice. The plate was relatively thin, only about $0.4 \mathrm{~m}$, located just above a depth of $8.0 \mathrm{~m}$. In Deadmoose Lake the dominant photosynthetic bacterium was Lamprocystis roseopercicina, an anaerobic purple sulphur bacterium. It grew at a deeper depth (below $8.8 \mathrm{~m}$ ) where there was less light energy and the water was colder (below $4^{\circ} \mathrm{C}$ ). Because these two species have slightly different ecological requirements, they are abundant in two lakes under different environmental conditions. Both bacteria occurred in each lake but one was always dominant.

Higher plants Rooted aquatic plants occur over a broad range of salinity. ${ }^{10}$ Submersed species also require enough light for photosynthesis. Only three submerged species (the fennel leaved pondweed Potamogeton pectinatus, the ditch grasses Ruppia maritima and R. occidentalis) occur in lakes greater than $5 \mathrm{~g} / \mathrm{L}$ salinity. The first two live in the hypersaline waters of Big Quill Lake $(53 \mathrm{~g} / \mathrm{L})$. P. pectinatus and $R$. occidentalis occur in Wakaw and Humboldt lakes but are also common in subsaline lakes. In saline lakes such as Redberry they were found down to a depth of 8 metres and were, presumably, light limited below this depth. These species provide habitat for fish and other aquatic animals as well as food for others such as ducks. A few other submersed species occur only in low salinity waters, e.g. the water milfoil 
Myriophyllum exalbescens.

Quite a few shallow water emergents were found to grow over a broad range of salinity. Scirpus paludosus (prairie bulrush) and Triglochin maritima (arrow-grass) were present over the entire salinity range investigated from Wakaw Lake to Whiteshore Lake. In the latter lake plants were growing in water where the salts were crystallized around the plant parts in the water. Both species looked very healthy. Seeds of both species are very important food sources for ducks. Scirpus americanus and $\mathrm{S}$. acutus occur in less saline but not subsaline waters. Two marginal emergents that grow in highly saline Muskiki Lake are Distichlis stricta (alkali grass) and Puccinellia nuttalliana (salt-meadow grass) but were also in slightly saline Porter Lake. Species such as Eleocharis palustris (spike-rush), Hippuris vulgaris (mare's tail) and the cattail Typha latifolia were restricted to low salinity waters as in Wakaw and Vanscoy lakes.

Many species invade lake substrates when the water recedes but normally do not grow in the water. Salicornia rubra (samphire), initially dark green, is the most spectacular when it matures with its bright red succulent foliage. Apparently, Natives used it for food seasoning. It occurs

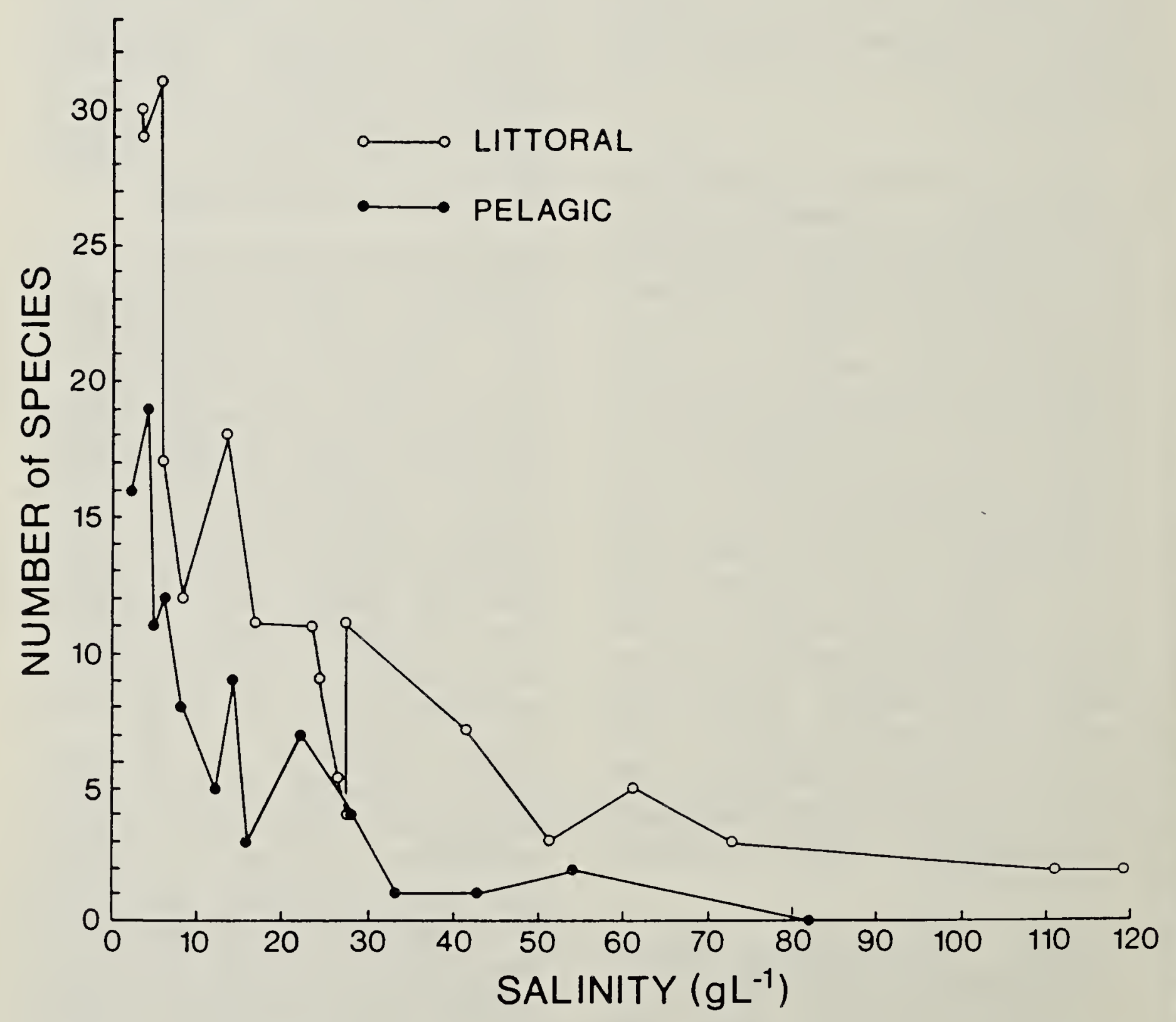

Figure 4. A comparison of species richness according to lake salinity in the littoral and pelagic zones of saline lakes in Saskatchewan and Alberta. 
in abundance around lakes such as Little Manitou, Redberry, Chaplin, Muskiki, Deadmoose and many others and is particularly obvious in the autumn. Goosefoot (Chenopodium rubrum), fox tail (Hordeum jubatum) and sow thistle (Sonchus arvensis) are also invaders in lower salinity soils such as beside Wakaw Lake.

Bottom fauna Benthos are animals which live on or in the bottom muds or on plants growing on the substrate. They are very important to lake ecology as they provide food for fish as well as waterfowl in shallower waters.

Twenty-three species were found in the deeper (pelagic) waters of 20 saline lakes in Saskatchewan and Alberta (Gooseberry, Killarney), ${ }^{19} 18$ species in $>10 \mathrm{~g} / \mathrm{L}, 10 \mathrm{in}>20 \mathrm{~g} / \mathrm{L}$ and only two in $>50 \mathrm{~g} / \mathrm{L}$ salinity lakes (Fig. 4). The amphipod (sideswimmer, scud) Hyalella azteca and the chironomids Procladius freemani, Chironomus nr. muratensis and Cryptochironomus spp. were most abundant in lower salinities (in up to $12 \mathrm{~g} / \mathrm{L})$, whereas the chironomids (midges) Tanypus nubifer, Cricotopus ornatus and Chironomus nr. annularis dominated at moderate salinities (5 to $30 \mathrm{~g} / \mathrm{L}$ ). Dolichopodid and ephydrid dipterans (flies) were the only species in hypersaline (50 $\mathrm{g} / \mathrm{L})$ deeper waters. Except for the sideswimmers, the other species are insects which spend their adult lives, usually short, out of the water while the immature stages are in the water where they may live as larvae for up to a year or more.

The pattern of species richness in shallow near shore (littoral) zones ${ }^{13}$ tended to follow a similar pattern to that in deep waters but the number of species was higher in each lake. Seventy-six species were identified in 18 lakes. In the lowest salinities
(Wakaw, Humboldt, Lenore) 29-31 species were present while only two species were present in highly saline Little Manitou Lake. Very high populations $(1,000-10,000$ or more per square metre) of amphipods (Gammarus lacustris and Hyalella aztecta), the ostracod Megalocypris ingens in Marie and Waldsea lakes, the chironomids Cricotopus ornatus Glyptotendipes and Tanypus nubifer and the water boatman Trichocorixa verticalis interiores were sometimes present.

Zooplankton These are the freeswimming microscopic animals present in the open water of lakes. They feed on algae or smaller zooplankton. The major groups are rotifers (wheel animalicules) and crustaceans including anostracans (such as brine shrimp), cladocerans (water fleas) and copepods. A total of 35 species were found in 20 lakes, including Gooseberry and Killarney in eastern Alberta. ${ }^{7}$ Species richness was greatest in salinities $<7 \mathrm{~g} / \mathrm{L}$ with 14-16 species per lake. Lakes with 7 to $100 \mathrm{~g} / \mathrm{L}$ salt had $6-8$ species while 2-5 species were present in lakes over $100 \mathrm{~g} / \mathrm{L}$ salinity (Aroma, Little Manitou, Whiteshore). The greatest densities occurred in lakes below 30 $\mathrm{g} / \mathrm{L}$ salinity.

As with other saline lake inhabitants, salinity is not the only limiting factor with respect to species survival and abundance. Two species (the rotifer Hexarthra polyodonta and the cladoceran Moina hutchinsoni) are restricted to high $\mathrm{pH}$ waters, $>\mathrm{pH}$ 9.0. Other factors which are involved are the food supply, water transparency, water temperature and water depth, but the effect of these factors is difficult to quantify in the field.

The brine shrimp Artemia is the only zooplankton species that has been consistently harvested in Saskatchewan. ${ }^{5}$ The adults are har- 




Figure 5. Annual harvest of brine shrimp (A) and their eggs (B) from Saskatchewan saline lakes.

vested with nets and sold to feed tropical fish in aquaria. Eggs are also collected and sold to tropical fish growers who hatch them for food for young fish. Chaplin and Little Manitou lakes are the prime sources. The annual harvest and value of shrimp and eggs is significant (Fig. 5). The standing crop of shrimp in Little Manitou Lake in the summer has been estimated at 5 million kilograms.

Fish Hammer $^{5}$ and Atton ${ }^{1}$ have discussed the occurrence of fish in saline Saskatchewan lakes. No endemic species occur in Saskatche- wan saline waters which have 15 fish species that otherwise are present in fresh waters. Most of these species are restricted to hyposaline waters (>20g/L salt) but the Nine-spine Stickleback (Pungitius pungitius) tolerates salinities up to $30 \mathrm{~g} / \mathrm{L}$, as in Deadmoose Lake. The minnow family (Cyprinidae) contributes five species to saline tolerant fauna, the stickleback family (Gasterosteidae) two species, four species in the perch family (Percidae) and two trout species (Salmonidae).

Reproduction only occurs at lower salinities, usually $6 \mathrm{~g} / \mathrm{L}$ or less, so in 
order to have gamefish populations in more saline lakes they have to be stocked periodically. Cisco and lake whitefish fry were stocked in the Quill Lakes during the 1920s and commercial netting was carried on from 1926-1930. Increasing salinity eliminated the populations after $1930 .{ }^{18}$ Rawson ${ }^{17}$ stocked Redberry Lake (15 $\mathrm{g} / \mathrm{L}$ salinity) with whitefish in 1940 and 1941 because it had abundant food (amphipods). Commercial fishing began in 1946 and continued until 1981 when the salinity rose to $>20 \mathrm{~g} / \mathrm{L}$ and the population succumbed. Stocking and commercial fishing of whitefish was also carried out in Basin and Lenore lakes. Over $700,000 \mathrm{~kg}$ of whitefish was harvested over the years, mostly from Redberry Lake.

Yellow Walleye fry were also introduced into Redberry Lake in 1941 and showed excellent growth. ${ }^{17}$ However, survival was better in less saline lakes so stocking was diverted to them (Fife, Fishing, Humboldt, Lenore, Little Quill, Tramping, Wakaw lakes) and carried out every two-three years. Over 40 million fry have been stocked and have led to a very successful sports fishery in hyposaline lakes. Successful stocking of perch and northern pike in lower salinity waters $<6 \mathrm{~g} / \mathrm{L}$ ) have been carried out periodically.

In the 1980 s rainbow trout (Salmo gairdneri) fingerlings were cageraised successfully in Redberry Lake in spite of its high salinity $(>23 \mathrm{~g} / \mathrm{L})$. Large-scale stocking was carried out in the spring of 1985 and excellent growth was noted in test netting late that year. However, spring netting in 1986 showed the complete absence of rainbows. It was determined that rainbow trout could not withstand the freezing point depression of the water temperature that occurred when the lake froze over in the autumn!

Birds Many species of waterfowl and other species of birds utilize saline lakes. ${ }^{5}$ Many species use the lakes as staging areas during spring and fall migration (Sandhill Cranes, various species of geese, ducks, swans, Double-crested Cormorants). Of special interest is the use of $\mathrm{Pa}$ tience Lake, particularly in the autumn, as a staging area by Canada Geese. Other waterfowl seem to avoid this lake since it has been polluted by the potash industry. Large numbers of Northern Phalaropes use saline lakes like the Quills and Chaplin as staging areas in their annual migrations.

Characteristic of saline lake margins are a great variety of waders including the American Avocet, Piping Plover (most of whose world population nests in the vicinity of prairie saline lakes) and the Killdeer. Bird sanctuaries have been established on the islands of Redberry Lake to provide opportunities for reproduction for the White Pelican, but California and Ring-billed Gulls, Black and Common Terns and White-winged Scoters also nest and feed there.

Recreation The utilization of saline lakes by man must be considered. I have already referred to angling for gamefish as well as commercial fishing. The hunting of waterfowl is an important fall pursuit on the Canadian prairies. Saline lakes provide temporary refuges for waterfowl as well as resting and feeding areas during this time.

Saline lakes also provide recreational facilities for many people. Little Manitou Lake was the site of a leading resort village in the first half of this century. ${ }^{2}$ It had many facilities 



Figure 6. The annual value $(A)$ and harvest $(B)$ of sodium sulphate in Saskatchewan. ${ }^{5}$

besides swimming and sand beaches. These included chalet pools, dancehalls and other tourist facilities, and was considered a health spa. With the opening of roads to northern Saskatchewan during the 1940s and 1950s, interest waned. Recently, interest in the area has been renewed and new facilities including a large indoor pool have been constructed. Cottage complexes have long been a feature at Manitou Beach.

Regional parks with summer cottage complexes have been established at a number of saline lakes
(Antelope, Cabri, Fife, Lenore, Little Manitou, Redberry, Tramping, Wakaw, Waldsea) where bathing and beach activities are available. Cottage developments are present at many other saline lakes including Humboldt and Manito. Potential resort development sites are at Basin, Big Quill, Little Quill and Lenore lakes.

Water activities are more attractive in many saline lakes because little algae is present and the water is usually clear. Sailing is an important pursuit in some lakes while power boating is less important. Humboldt 
Lake has one of the most active water ski clubs in Saskatchewan. Canoeing and board sailing are widely practiced. Less strenuous pursuits include bird watching, photography, hiking and observing aquatic flora and fauna.

Minerals More highly saline lakes are major sources of minerals. ${ }^{5}$ Eight plants harvest sodium sulphate (Fig. 6 ) which is used mainly in the pulp and paper industry which uses $20 \mathrm{~kg}$ per tonne of pulp produced. It is also used in the glass industry, in tanning and dyeing, in textile manufacturing and in detergents as a builder. Estimated deposits are 200 million tons, the largest deposits in the world. Big Quill, Little Manitou and Redberry lakes contain 2,200,000, 2,500,000 and $1,850,000$ tons of magnesium sulphate respectively. Some is now being extracted from Big Quill Lake to produce chemical grade product. Epsom salts is another product while magnesium is a widely used metal. Commercial quantities of other minerals (potassium sulphate, magnesium chloride, halite, gypsum) are present but other sources are cheaper now.

Economics The saline lakes are worth millions of dollars annually to the people of Saskatchewan. Local people and tourists spend a great deal of money on sports fishing, waterfowl hunting and on recreational activities. The brine shrimp industry and the extraction of minerals has been developed by a number of businesses and provide good returns. Employment associated with saline lake investments is considerable.

1. ATTON, F.M. 1986. Fish in Saskatchewan endorheic systems and saline lakes. In D.T. Waite (ed.). Evaluating saline waters in a plains environment. Canadian Plains Proc. 17:65-74. Canadian Plains Research Center, Uni- versity of Regina, Regina.

2. BAKER, R.L. 1965. Recreation prospects associated with the proposed Blackstrap Reservoir and the improvement of water levels of Little Manitou Lake. Park and Outdoor Education Branch, Saskatchewan Department of Natural Resources, Regina. $160 \mathrm{pp}$.

3. 1978. The saline lakes of Saskatchewan. III. Chemical characterization. Int. Revue ges. Hydrobiol. 63:311-335.

4. - 1986a. saline lake ecosystems of the world. Monographiae Biologicae 59. Junk, Dordrecht, The Netherlands, $602 \mathrm{pp}$.

5. - 1986b. Saline lake resources of the Canadian prairies. Canadian Water Resources J. 11:43-57.

6. 1988. Water resources and their utilization in Saskatchewan, Canada. verh. Internat. Verein. Limnol. 23:228-233.

7. - 1993. Zooplankton distribution and abundance in saline lakes of Alberta and Saskatchewan, Canada. Int. J. Salt Lake Research 2:111-132.

8. 1994 . Life and times of five Saskatchewan saline meromictic lakes. Int. Revue ges. Hydrobiol. 79:235248.

9. HAMMER, U.T., and R.C. HAYNES. 1978. The saline lakes of Saskatchewan. II. Locale, hydrogeography and physical effects. Int. Revue ges. Hydrobiol. 63:179-203.

10. HAMMER, U.T. and J.M. HESELTINE. 1987. Aquatic macrophytes in saline lakes of the Canadian prairies. Hydrobiologia 158:101-116.

11. HAMMER, U.T. and R.D. PARKER. 1984. Limnology of a perturbed highly saline Canadian lake. Arch. Hydrobiol. 102:31-42.

12. HAMMER, U.T., J. SHAMESS and R.C. HAYNES. 1983. The distribution and abundance of algae in saline lakes of Saskatchewan, Canada. Hydrobiologia 105:1-26.

13. HAMMER, U.T., J.W. SHEARD and J. KRANABETTER. 1990. Distribution and abundance of littoral benthic fauna in Canadian prairie saline lakes. Hydrobiologia 197:173-192. 
14. HAYNES, R.C. and U.T. HAMMER. 1978. The saline lakes of Saskatchewan. IV. Primary production by phytoplankton in selected saline ecosytems. Int. Revue ges. Hydrobiol. 63:337-351.

15. LAWRENCE, J.R., R.C. HAYNES and U.T. HAMMER. 1978. Contribution of photosynthetic bacteria to total primary production in a meromictic saline lake. Verh. Internat. Verein. Limnol. 20:201-207.

16. PARKER, R.D. and U.T. HAMMER. 1983. A study of Chromatiaceae in a saline meromictic lake in Saskatchewan, Canada. Int. Revue ges. Hydrobiol. 68:839-851.
17. RAWSON, D.S. 1946. The successful introduction of fish into a large saline lake. Can. Fish Culturist 1:5-8.

18. RAWSON, D.S. and J.E. MOORE. 1944. The saline lakes of Saskatchewan. Can. J. Research D22:141-201.

19. TIMMS, B.V., U.T. HAMMER and J.W. SHEARD. 1986. A study of benthic communities in some saline lakes in Saskatchewan and Alberta, Canada. Int. Revue ges. Hydrobiol. 71:759-777.

20. VALLENTYNE, J.R. 1972. Freshwater supplies and pollution: effects of the demorphic explosion on water and man. Pages 181-211 In N. Polunin (ed.). The environmental future. MacMillan, New York.

21. WILLIAMS, W.D. 1964. A contribution to lake typology in Victoria, Australia. Verh. Internat. Verein. Limnol. 15:158-163.

So important are insects and other land-dwelling arthropods that if all were to disappear, humanity probably could not last more than a few months. Most of the amphibians, reptiles, birds, and mammals would crash to extinction about the same time. Next would go the bulk of the flowering plants and with them the physical structure of most forests and other terrestrial habitats of the world. The land surface would literally rot. As dead vegetation piled up and dried out, closing the channels of the nutrient cycles, other complex forms of vegetation would die off, and with them all but a few remnants of the land vertebrates. The free-living fungi, after enjoying a population explosion of stupendous proportions, would decline precipitously, and most species would perish. The land would return to approximately its condition in early Palaeozoic times, covered by mats of recumbent wind-pollinated vegetation, sprinkled with clumps of small trees and bushes here or there, largely devoid of animal life: Wilson, E.O. 1992. The diversity of life. W.W. Norton and Company, New York. 424 pp. 